\title{
2,
}

\section{THE NUMERICAL ANALYSIS OF WELDABILITY IN THE DESIGN AND TECHNOLOGICAL PROCESSES INFLUENCE ON THE EXPLOITATION CONDITION AND QUALITY}

\section{RELACJA ILOŚCIOWA ANALIZY SPAWALNOŚCI W UKLADZIE KONSTRUKCJA - TECHNOLOGIA I ICH WPLYW NA JAKOŚĆ DZIAŁANIA OBIEKTÓW TECHNICZNYCH}

\author{
Eugeniusz Ranatowski ${ }^{1}$, Lukasz Muślewski ${ }^{2}$ \\ $(1,2)$ University of Technology and Life Science, Mechanical Department, \\ Chair of Material Science and Engineering, \\ Uniwersytet Technologiczno - Przyrodniczy im. Jana i Jędrzeja Śniadeckich, \\ Wydział Mechaniczny, Katedra Inżynierii Materiałowej \\ ul. Prof. S. Kaliskiego 7, 85-791 Bydgoszcz \\ e-mails: (1) ranatow@utp.edu.pl, (2) l.muslewski@wp.pl
}

\begin{abstract}
Numerical weldability analysis is a new powerful research and development tool which is useful for metallurgists, technologist and design engineers. Saying strictly the numerical analysis of weldability comprises thermodynamic, thermomechanical and microstructural modelling of the welding process. The result of this analysis is material susceptibility (SU). The fracture resistance of welded joints is mainly characterised by normalised parameters: $K_{I t h} / K_{I C} ; \delta / \delta_{c}, J / J_{c}$; in the exploitation condition. From above-mentioned equations results that does not exist one global parameter which defines the step of susceptibility SU of base materials has been also executed with use of SINTAP program and Computational Welding Mechanics (CWM).
\end{abstract}

Keywords: weldability, CWM, mathematical modelling, fracture mechanics, exploitation, quality.

Streszczenie: Systemy zapewnienia jakości produkcji są ukierunkowane na rozwój nowoczesnych metod projektowania konstrukcji oraz technologii ich wytwarzania. Należy w tym miejscu podkreślić znaczący rozwój metalurgii i fizyki procesu spawania obejmujący m.in. hydrodynamikę jeziorka spawalniczego $\mathrm{z}$ uwzględnieniem sił powierzchniowych i objętościowych różnego pochodzenia a także modelowania procesu krystalizacji SP i morfologii przemian strukturalnych w SWC. Ponadto do oceny SU materiału praktycznie usiłuje się stosować normalizowane parametry mechaniki pękania np. $\mathrm{K}_{\mathrm{Ith}} / \mathrm{K}_{\mathrm{IC}} \mathrm{W}$ warunkach pękania zimnego lub w warunkach eksploatacyjnych $\delta / \delta_{\mathrm{c}}$ lub $\mathbf{J} / \mathbf{J}_{\mathrm{c}}$. Wyżej wymienionym rozwiązaniom nadano również charakter bardziej szczegółowy bazując m.in. na ustaleniach procedur SINTAP oraz Obliczeniowej Mechaniki Spawania OMS.

Słowa kluczowe: spawalność, OMS, matematyczne modelowanie, mechanika pękania 


\section{THE NUMERICAL ANALYSIS OF WELDABILITY IN THE DESIGN AND TECHNOLOGICAL PROCESSES INFLUENCE ON THE EXPLOITATION CONDITION AND QUALITY}

\section{Introduction}

Currently the welding technique is widely used in the modern industry. Development of welding process is expressed in structure of the new constructions and characterized by the high level of reliability, safety and efficiency of operation. For example welding can be used in the ship building industry and in the construction of large offshore drilling and production platforms. Recently it has been applied to airframe fabrication, in aerospace industry, sea and road transport and in micro and nanotechnology.

This progress is a result of:

- elaboration of high strength and special steels; the micro - structural models are in many cases sufficiently advanced to give accurate predictions for welds and HAZ,

- elaboration of modern design solutions with the use o: laser welding, electron welding and plasma welding or other conventional material joining technologies,

- application of the physical rules into description of the welding process. Till now the potential of quantitative weldability analysis and method in the design process is not so clear.

Currently the welding as a technological process is concerned as a special process, the results of which cannot be checked in a complete degree by the subsequent control, test of production or when, for example, the defects can be revealed only at operation of a product. According to the concept "Assurance of quality" of the German Federal Ministry of Science and Technology, about $75 \%$ of the defects of the future products "arise" at the design and technological stage of production. Therefore the system of measurement on assurance of quality of production at the engineering stage of production should be directed on the development of modern methods of designing of welded constructions and technology of their manufacture. Good modelling techniques can reduce the time from conception to production, can provide quantitative tools of lasting value and permit a reliable and easy route for transfer of technology between science and 
industry. Basic science is not yet to challenge the necessary problems. Numerical weldability analysis is a new powerful research and development tool which is useful for metallurgists, technologist and design engineers and presently is based on the Computational Welding Mechanics (CWM) [5].

CWM has also an influence on safety and reliability of the systems and technical objects. Predicting and simulating the periods of required or correct operation quality of the structural elements being operated and maintained are essential tasks in the design, process engineering and production processes and they affect their operation and maintenance process.

\section{Computational Welding Mechanics and its influence on the quality of welded joints.}

The objective in Computational Welding Mechanics (CWM) is to extend the capability to analyse the temperature, stress and strain in welded structures together with the evolution of microstructure. Distortion caused by volumetric strains due to thermal expansion and phase transformations are a dominate load in the stress analysis. The microstructure evolution influences the constitutive equations. The mechanical behaviour of welded joints is sensitive to the close coupling between the modules: (HT) - heat transfer, (ME) - microstructure evolution and (MF) - mechanical fields.

Although the effects of microstructure and stress - strain evolution on heat transfer are not large, the effect of temperature on the microstructure and thermal stress is dominant. In addition, the coupling between microstructure and thermal stress can be strong and subtle. The modelling of the fluid flow in weld is not included, because the effect of the fluid flow on the deformation and stress field is negligible [5]. In the past years considerable progress has been made in developing numerical methods to solve this coupled problem with increasing speed and accuracy. Realistic welds may involve numerous passes, each of which contributes to mechanical and metallurgical effects [2].

There exists an overwhelming number of approaches to and results from empirically and theoretically based mathematical models of weldability, i.e. welding processes, of material behaviour in welding and the strength of welded structures. The microstructure development in the weld metal region is most complicated. This complication arise because of various physical processes that occur in the arc plasma vapour state, weld metal liquid state and solid state. The result of the each physical process that dominates at higher temperature influences the phase changes at lower temperature. For 
example, physical processes such as elemental transport in the weld metal, evaporation of alloying elements from the weld metal and gas - metal reactions control the final composition. The weld metal composition, in turn, controls the microstructure development during solidification and solid state transformations. This type of sequential dependency of microstructure development in weld metals exist in almost all alloy systems [2].

In it's narrowest sense computation weld mechanics is concerned with the analysis of temperatures, displacements, strains and stresses in welded structures. In its broadest context, it is an important element of Computer Aided Design (CAD) and Computer Aided Manufacturing (CAM). The mathematical modelling allows optimisation of the numerous influencing parameters with the aim to increase the process reliability and to improve the welding construction properties. It means that the modelling of welding processes requires taking into account the physical phenomena and their interactions. The analysis of the welding process from above point of view, enables to execute the algorithm which is presented in Fig.1.

The assessment of the step susceptibility of the base material on welding process is finally lean upon the structure toughness parameter. The result of this analysis is material susceptibility (SU). The structure resistance of welded joints is mainly characterized by normalized parameters:

- for cold cracking:

$S U_{I}=K_{I t h} / K_{I C}$

- in the exploitation condition:

$S U_{2}=\delta / \delta_{c} \neq J / J_{c}$

$S U_{1} \neq S U_{2}$

From above - mentioned equations (1-3), base on the fracture mechanic parameters, result that does not exist one global parameter which defines the step of susceptibility (SU) of base materials has been executed with use of SINTAP programme.

An example of this sequential dependency of microstructure development in low-alloy steel weld metal is analysed [4]. The steel weld pool region is usually heated to temperature as high as $2500 \mathrm{~K}$. As the weld metal cools from above temperature, in the temperature range 2300 to $1800 \mathrm{~K}$, the dissolved oxygen and deoxidising elements in liquid steel react to form complex oxide inclusions of 0,1 to $1 \mu \mathrm{m}$ size range.

The phase transformation from $\delta$ ferrite to austenite controls the austenite grain size which, in turn, controls the transformation kinetics of austenite to allotriomorphic ferrite. In the temperature range $1100-500^{\circ} \mathrm{K}$ the austenite 
transforms to different ferrite morphologies: allotriomorphic ferrite, As characterised earlier, the ultimate weld metal composition will be decided by the physical processes that occur in the arc plasma. It is practically impossible to model the microstructure development without considering the influence of all the relevant physical processes.

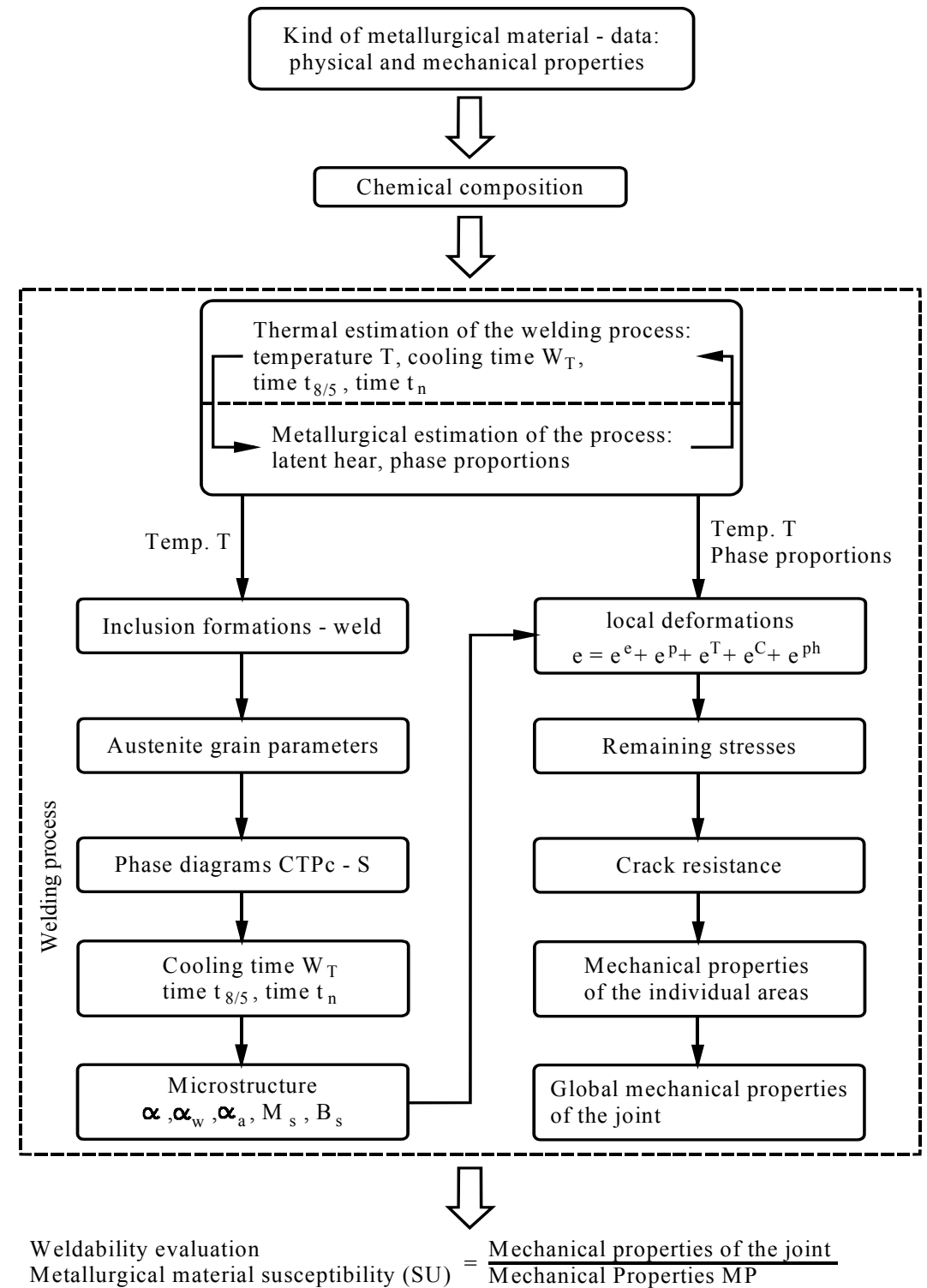

Fig. 1. Diagram of calculating microstructure and properties of SP and SWC, where:

$\varepsilon, \varepsilon^{e}, \varepsilon^{p}$ $\varepsilon^{T}, \varepsilon^{c}, \varepsilon^{p h}$ are respectively complete deformation, elastic, - plastic, thermal, creep and phase transformations . 
Till now, an integrated model that comprises all of the above processes is yet to be developed. The development of such a model depends on the identification of various modelling tools for the fundamental description of various physical processes that occur in welds. Various models tend to solve the fundamental differential equations governing physical processes either by deterministic analytical techniques or numerical methods. In the models describing phase change, thermodynamic descriptions of phases are needed. This data can be obtained from published experiments and used to compute phase diagrams. In addition, tools such as differential thermal analysis and differential scanning calorimetry can be used to evaluate some key parameters such as: heat of fusion, stored strain energy, transformation temperatures needed for modelling microstructure development in welds.

\section{Weld quality as a component in the method to evaluate technical object operation}

This method concerns evaluation of the operation quality of the complex sociotechnical systems and the technical objects being operated and maintained within them. The system is a set of the elements, relations between them and the function of goals. The elements of the systems are the objects - the technical devices, their components, among them there also such ones whose joints were made by mans of welding. The operation quality of the systems (or their elements) is described by a set of significant features, expressed by means of numerical values, at the given moment $t$, determining the degree of fulfilment of the requirements [7]. The quality term defined that way was the basis to build a quality evaluation model.

In order to build such a model, it is needed to determine a set of quality significant features $Z=X_{i}, i=1,2, \ldots, p$ which is divided into $n-$ separable subsets $\mathrm{Z}_{1}, \mathrm{Z}_{2}, \ldots, \mathrm{Z}_{\mathrm{n}}$ fulfilling the relationship:

$$
\begin{aligned}
& Z_{i} \cap Z_{j}=\varnothing \text { for } i \neq j ; \\
& Z(t)=Z_{1}(t) \cup Z_{2}(t) \cup \ldots \cup Z_{n}(t)
\end{aligned}
$$

Each of the $n$-th subsets of $Z_{i}$, where: $i=1,2, \ldots, n$, is a component of the feature set describing the operation quality of the entire system [7]. Thus the general form of the model may be expressed with the following relationship: 


$$
\begin{aligned}
& Z_{1}(t)=\left\{X_{1}(t), \ldots, X_{k_{1}}(t)\right\} \\
& Z_{2}(t)=\left\{X_{k_{1}+1}(t), \ldots, X_{k_{2}}(t)\right\} \\
& Z_{3}(t)=\left\{X_{k_{2}+1}(t), \ldots, X_{k_{3}}(t)\right\} \\
& \ldots \\
& Z_{n}(t)=\left\{X_{k_{n}-r}(t), \ldots, X_{k_{n}-1}(t), X_{k_{n}}(t)\right\}
\end{aligned}
$$

where:

$\mathrm{k}_{\mathrm{n}}=\mathrm{p} ; \mathrm{n} \leq \mathrm{p} ; \mathrm{k}, \mathrm{n}, \mathrm{r}, \mathrm{p} \in \mathrm{N}$;

$Z_{i}$ - feature subsets describing quality of the individual system element subsets $\mathrm{E}_{\mathrm{i}}$,

$E_{i}$ - system element subsets,

$\mathrm{X}_{\mathrm{i}}$ - feature set comprehensively describing the system quality , $\mathrm{i}=1,2, \ldots, \mathrm{p}$, $\mathrm{i}=\left\{1<\ldots<\mathrm{k}_{1}<\mathrm{k}_{1}+1<\ldots<\mathrm{k}_{2}<\mathrm{k}_{2}+1<\ldots<\mathrm{k}_{\mathrm{n}}-\mathrm{r}<\ldots<\mathrm{k}_{\mathrm{n}}-1<\mathrm{k}_{\mathrm{n}}=\mathrm{p}\right\}$.

In case, when one of the criterion is the evaluation of weldability of the structural elements of a respective technical object $\left(Z_{\mathrm{k}}\right)$, then according to the diagram presented in the Fig. 1, such a criterion will be described with two feature sets regarding: physical and mechanical properties and chemical composition of the materials, the elements of the technical objects are made of. In the first of the aforementioned sets it is possible to distinguish two subsets containing the features regarding metallurgy and material structure $\mathrm{Z}_{\mathrm{ms}}(\mathrm{t})$ [inclusion formation, austenite grain parameters, phase diagrams CTPc-S, cooling time and microstructure $\left.-Z_{\mathrm{ms} 1}(\mathrm{t})-\mathrm{Z}_{\mathrm{ms} 5}(\mathrm{t})\right]$ as well as mechanical properties $Z_{m}(t)$ [local deformations, remaining stresses, crack resistance, mechanical properties of the individual areas, global mechanical properties of the joint $\left.-Z_{m 1}(t)+Z_{m 5}(t)\right]$.

Therefore, a part of the evaluation model, regarding the weld quality $\left(Z_{k}\right)$ may be described with the relationship:

$Z_{k}(t)=Z_{m s}(t)+Z_{m}(t)$

where:

$Z_{\mathrm{ms}}(\mathrm{t})=\mathrm{Z}_{\mathrm{ms} 1}(\mathrm{t})+\mathrm{Z}_{\mathrm{ms} 2}(\mathrm{t})+\mathrm{Z}_{\mathrm{ms} 3}(\mathrm{t})+\mathrm{Z}_{\mathrm{ms} 4}(\mathrm{t})+\mathrm{Z}_{\mathrm{ms} 5}(\mathrm{t}) ;$

$\mathrm{Z}_{\mathrm{m}}(\mathrm{t})=\mathrm{Z}_{\mathrm{m} 1}(\mathrm{t})+\mathrm{Z}_{\mathrm{m} 2}(\mathrm{t})+\mathrm{Z}_{\mathrm{m} 3}(\mathrm{t})+\mathrm{Z}_{\mathrm{m} 4}(\mathrm{t})+\mathrm{Z}_{\mathrm{m} 5}(\mathrm{t})$.

then:

$$
\begin{aligned}
& Z_{k}(t)=\left[Z_{m s 1}(t)+Z_{m s 2}(t)+Z_{m s 3}(t)+Z_{m s 4}(t)+Z_{m s 5}(t)\right]+ \\
& +\left[Z_{m 1}(t)+Z_{m 2}(t)+Z_{m 3}(t)+Z_{m 4}(t)+Z_{m 5}(t)\right]
\end{aligned}
$$


The welding joint quality, described with the relationship (5), is a component of the workmanship evaluation of a respective element and subsequently of a technical object - of a machine, of a device which in turn has a direct influence on the operation quality of the system in which it is being operated and maintained.

\section{Evaluation of the weld FM as a result of HT and ME on an example of an increased cracking rate}

According to Fig.1 the solute distribution during weld pool solidification is an important phenomenon resulting in segregation that can significantly affected the mechanical properties. Due to the nature of the welding process it is difficult to assure the quality of individual weldments, and in general weldments contain many more flaws than surrounding material. Therefore it is important to understand the effects of mismatching in order optimise the cost, strength and toughness of steel weldments and correct evaluation of weldability and consequently safety and reliability of the technical objects or their elements being operated and maintained. The welds contain large inclusions, e.g. manganese sulphides, and small inclusions, e.g. carbides and complex oxide inclusions. It is therefore desirable to design a model, capable of illustrating the microscopic process near the crack tip. Very interested model is proposed by Broberg K.B. [2].

The particles and holes in the material are assumed to be cylindrical and the particle size and positions are randomly distributed.

Finally, the stress $\sigma$ at a hole is calculated from the overall stress field, which is taken as [2]:

$$
\sigma=\frac{K}{\sqrt{\pi(r+\delta)}+\sqrt{\pi r}}\left(\frac{\sqrt{1-\left(V^{2} / c_{d}^{2}\right) \sin ^{2} \Theta}+\cos \Theta}{1-\left(V^{2} / c_{d}^{2}\right) \sin ^{2} \Theta}\right)^{1 / 2},
$$

where: K- stress intensity factor,

V - crack tip velocity,

$c_{d}$ - propagation velocity of irrotational waves,

$\mathrm{r}, \Theta$ - polar coordinates with origin at the crack tip,

$\delta \quad$ - is introduced in order to remove the singularity.

Beside, the following rules are adopted:

- a hole grows according to a viscosity rule is calculated as

$\frac{1}{a} \frac{d a}{d t}=\beta\left(\frac{\sigma}{\sigma_{o}}-1\right)^{n}$

$\sigma>\sigma_{0}$ 
where: a - hole radius,

$\mathrm{t}$ - time,

$\beta$ - fluidity parameter (constraint value),

$\sigma_{0}-$ constraint stress.

- a hole opens at particle " $\mathrm{i}$ " when the stress overshoots a certain critical value $\sigma_{\mathrm{cr}}$, which is dependent on the particle size and the expression is chosen:

$\sigma_{c r}^{(i)}=s_{o f} \sigma_{o}\left[1+\left(\frac{b_{o}}{a_{i}}\right)^{1 / 2}\right]$

where: $a_{i}$ - particle radius,

$b_{o}$ - a standard particle radius,

$s_{o f}-a$ factor characteristic for the particle - matrix combination.

In equations (7), (8) the stress at a hole is calculated from eq. (6) and $\delta$ in form:

$\delta=\frac{\kappa K^{2}}{\sigma_{o}^{2}}$

For example, if $\kappa=0.025$ then [2]:

$\sigma_{\max }=\frac{\sigma_{o}}{(0.025 \pi)^{1 / 2}}=3.6 \sigma_{o}$

In addition to (6) comes stress reduction due to opened neighbouring holes. The equations $(6 \div 10)$ present mathematical characteristic of a model, capable of interpreting the microscopic process near the crack tip - with taken into consideration small particle - intrusion and constraint effect because of mismatching of materials. This problem somewhat otherwise is defined also in macroscopic scale in works $[1,6]$ and constraint based approaches to fracture assessment are now used. Within SINTAP (structural integrity assessment procedures for European industry) these practical issues have been addressed in order to include constraint - based approaches within an overall defect assessment procedure. Finally, within the SINTAP procedure, results may be presented by methods based on:

- a crack driving force (CDF), or

- a failure assessment diagram (FAD).

For example the three different constraint parameters for plates under uniaxial and biaxial tension are defined by [1]:

$Q=\left(\sigma_{\Theta \Theta}-\sigma_{\Theta \Theta}^{s s y}\right) / \sigma_{y}$, 
$\Theta_{m}=\left(\sigma_{h}-\sigma_{h}^{s s y}\right) / \sigma_{y}$,

$H=\sigma_{h} / \sigma_{e}-\left(\sigma_{h} / \sigma_{e}\right)^{s s y}=h-h^{s s y}$,

where: $\sigma_{\Theta \Theta}$ - crack opening stress,

$\sigma_{\mathrm{h}}-$ hydrostatic stress,

$\sigma_{\mathrm{e}}$ - Huber-von Mises effective stress.

The ssy solution is chosen as a reference field with high crack-tip constrain and all quantities in eqs. $(11 \div 13)$ are evaluated at a distance $\mathrm{r} /\left(\mathrm{J} / \sigma_{\mathrm{y}}\right)=2$ from the crack tip in a cylindrical coordinate system $(\mathrm{r}, \Theta)$ centred at the crack tip under plane strain conditions. Above solution indicate that constraint effects at the crack tip can cause marked differences in the fracture behaviour of different geometrics. Similar effects also occur from different degrees of mismatching of welds. Fig. 2 it presents some results of modelling and estimate effect of material mismatch [3].

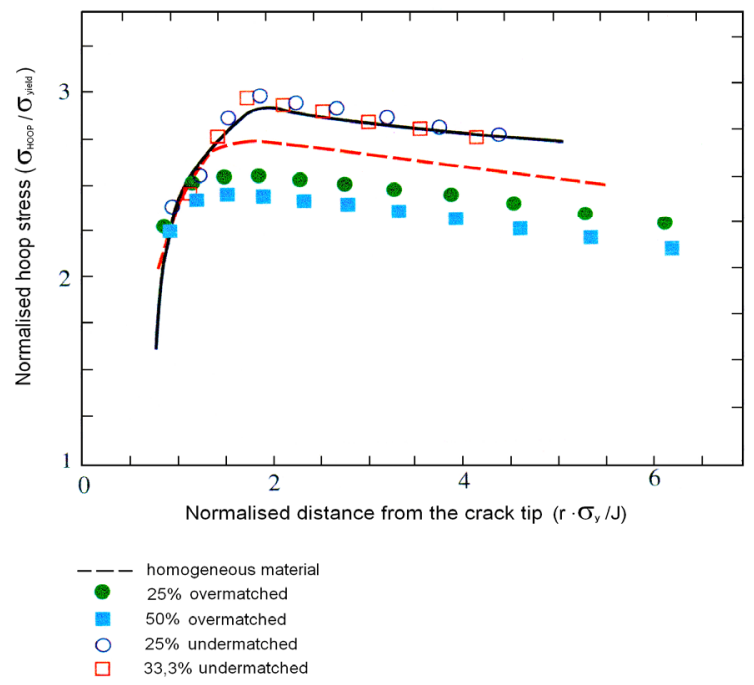

Fig. 2. The distribution of stress ahead of a crack [3]

At first the distribution of stress ahead of a crack which is seen to be much lower for an overmatched joint than for the homogeneous case - Fig. 2. The change in constraint exhibited in mismatched weld is related to the J-CTOD relationship predicted from the slip-line field solution as function of constraint term $\Theta \sigma_{y} / \sigma_{\text {ssy. }}$. The final question is assessment of the step of susceptibility $\mathrm{SU}$ of welded joints on welding process. The physical measure of this phenomena we can accept the fracture resistance of welded joints mainly characterised by fracture mechanics parameter in normalised form. Numerical weldability analysis is a new powerful research and development tool which is useful for metallurgists, technologists and design engineers. Saying strictly the numerical analysis of weldability comprises 
thermodynamic, thermomechanical and microstructural modelling of the welding process.

The result of this analysis is material susceptibility (SU). The fracture resistance of welded joints is mainly characterised by normalised parameters: $\mathrm{SU}_{1}=\mathrm{K}_{\mathrm{Ith}} / \mathrm{K}_{\mathrm{IC}}$ for cold cracking or in the exploitation condition by $\mathrm{SU}_{2}=\delta / \delta_{\mathrm{c}}$ or $\mathrm{J} / \mathrm{J}_{\mathrm{c}}, \mathrm{SU}_{1} \neq \mathrm{SU}_{2}$. From above-mentioned equations result that does not exist one global parameter which defines the step of susceptibility SU of base materials has been also executed with use of SINTAP program.

\section{Summary}

A definition for numerical analysis of the weldability is given and the new aspects of the weldability assessment is presented. The paper explains the sequential dependency of each of the physical processes in the welding situation and based on the (CWM).

The importance of the fundamental understanding of mechanisms of physical processes in welded joints and the validation of models with advanced experimental tools is also emphasised. The numerical analysis of weldability also influence on the exploitation condition and quality.

Finally, the basic characteristic of strains, stress, constraint effect and normalised fracture mechanics parameters as measure of the susceptibility are presented.

\section{References}

1. Ainsworth R.A. et al., Methods for including constraint effects within the SINTAP procedures. Engineering Fracture Mechanics, Vol. 67, Issue $6,2000$.

2. Broberg K.B.: Computer demonstration of crack growth. International Journal of Fracture. 42, 1990.

3. Burstow M.C.: Analysis of welded joints. SIRIUS. 1996.

4. David S.A., Babu S.S., Microstructure modelling in weld metal. Mathematical Modelling of Weld Phenomena 3. Edited by H. Cerjak. The Institute of Materials. London, 1997.

5. Goldak J.A., Akhlanghi M.: Computational Welding Mechanics. Springer. ISBN-13: 978-0387-23287-4, springeronline.com.

6. Ranatowski E.: The influence of the constraint effect on the mechanical properties and Weldability of the Mismatched Weld Joints. Mathematical Modelling of Weld Phenomena 8. Edited by H. Cerjak, H. Bhadeshia, E. Kozeschnik. TU Graz, 2007.

7. Woropay M., Muślewski Ł.: Quality in system captivation. ITeE, Bydgoszcz - Radom, 2007. 


\section{RELACJA ILOŚCIOWA ANALIZY SPAWALNOŚCI W UKLADZIE KONSTRUKCJA - TECHNOLOGIA I ICH WPLYW NA JAKOŚĆ DZIALANIA OBIEKTÓW TECHNICZNYCH}

\section{Wstęp}

Rozwój spawalnictwa jako techniki wytwarzania, który obserwujemy w ostatnich latach wyraża się w sposób praktyczny w budowie nowych jakościowo konstrukcji, charakteryzujących się wysokim poziomem niezawodności, bezpieczeństwa i efektywności działania np.:

- olbrzymich spawanych platform wiertniczych, pracujących w bardzo trudnych warunkach Morza Północnego,

- konstrukcji spawanych mających zastosowanie w energetyce jądrowej, przemyśle lotniczym i kosmicznym, transporcie morskim, lądowym oraz w mikro i nanotechnologii.

Postęp ten jest, między innymi, wynikiem:

- opracowania i wdrożenia do praktyki przemysłowej stali o podwyższonej i wysokiej wytrzymałości oraz innych materiałów o specjalnych właściwościach fizycznych oraz mechanicznych, połączony z równoczesnym rozpracowaniem złożonych zagadnień ich spawalności,

- opracowania nowoczesnych rozwiązań konstrukcyjnych z użyciem metod spawania opartych o wysokoskoncentrowane źródła ciepła np. strumień plazmy, laser, wiązka elektronów oraz mechanizacji i automatyzacji procesu spawania aż do jego robotyzacji,

- odkrycia nowych zjawisk z podstaw fizycznych procesu spawania.

Należy jednakże stwierdzić, iż pomimo niewątpliwych osiagnięć w zakresie rozwoju spawalnictwa $\mathrm{i}$ jego zastosowania $\mathrm{w}$ technice nie udało się doprowadzić do takiego postępu, aby stosowanie spawania było prostsze, a liczba problemów do rozwiązania wcale nie zmalała. Jednym z takich problemów jest fundamentalny, dla właściwego opracowania technologii spawania, problem oceny spawalności, stanowiący punkt wyjścia dla opracowania technologii spawania. Aktualnie spawalnictwo uważane jest jako proces technologiczny o charakterze specjalnym, którego rezultaty nie mogą być sprawdzone w całkowitym stopniu w następstwie kontroli lub testów produkcyjnych. Powyższe stwierdzenie jest zgodne m.in. $\mathrm{z}$ 
koncepcją „Niemieckiego Ministerstwa Nauki i Technologii”, iż około 75\% wad przyszłej produkcji powstaje na etapie konstruowania i technologicznego opracowania produkcji. W związku $\mathrm{z}$ tym systemy zapewnienia jakości produkcji są ukierunkowane na rozwój nowoczesnych metod projektowania konstrukcji oraz technologii ich wytwarzania. Praktycznie, zgodnie m.in. z EN 729, działania inżynierskie ukierunkowane są $\mathrm{z}$ jednej strony na próby praktyczne spawania a z drugiej - teoretycznej opierają się na systemach ekspertowych, bazujących na komputerowych symulacjach fizycznych procesów.

Reasumując, jednym z istotnych osiagnięć współczesnej myśli technicznej jest pogłębiona wiedza inżynierska o przebiegu procesów technologicznych, wyrażona przez „Obliczeniową Mechanikę Spawania” (OMS) [5].

OMS wpływa również na bezpieczeństwo i niezawodność systemów i obiektów technicznych. Przewidywanie i symulacja okresów, pożądanej lub poprawnej jakości działania, eksploatowanych elementów konstrukcyjnych, są podstawowymi zadaniami w procesach projektowania, technologii oraz wytwarzania i bezpośrednio wpływają na proces ich eksploatacji.

\section{Obliczeniowa mechanika spawania - i jej wpływ na jakość wykonywanych polączeń spawanych}

Celem „OMS” jest rozszerzenie możliwości analizy: temperatury, naprężeń i odkształceń razem $\mathrm{z}$ ewolucją mikrostruktury w procesie spawania. Zniekształcenie spowodowane przez objętościowe natężenie materiału $\mathrm{w}$ wyniku termicznej ekspansji oraz fazowej transformacji, generuja dominujące obciążenie w procesie analizy naprężeń.

W zawężonym sensie OMS obejmuje więc relację złożoną, o sprzężeniu zwrotnym, co w sensie fizycznym prowadzi do ustalenia związku pomiędzy modułami: polem termicznym (PT) - ewolucją mikrostruktury (EM) polem mechanicznym (PM) o wzajemnym oddziaływaniu synergicznym. Ocena wzajemnych relacji pomiędzy ww. modułami powinna więc polegać na analizie wymiarowej powyższych modułów PT-PM-EM, przy ścisłym zapisie fizykalnym zachodzących $\mathrm{w}$ nich procesów. Występuje tu również wyraźna asymetria pomiędzy (PT), (PM) a (EM). W szerszym kontekście OSM obejmuje także elementy komputerowego wspomagania procesu konstruowania (CAD) oraz wytwarzania (CAM). Moduły (PT), (PM) oraz (EM) stanowią podstawy do budowy algorytmów stosowanych w rozwiązaniu teoretycznym praktycznych zagadnień inżynierskich z zakresu spawalnictwa. 
Scharakteryzujmy więc aktualnie stosowaną metodykę badawczą $\mathrm{w}$ formie schematu blokowego obliczeń mikrostruktury i właściwości spoiny (SP) oraz strefy wpływu ciepła (SWC) - Rys.1 [6] Prowadzi to w ostatecznym rezultacie, po uwzględnieniu procedury przedstawionej na Rys.1, do oceny stopnia uwrażliwienia (SU) materiału hutniczego na proces spawania i oceny jego spawalności.

Należy w tym miejscu podkreślić znaczący rozwój metalurgii i fizyki procesu spawania obejmujący m.in. hydrodynamikę jeziorka spawalniczego z uwzględnieniem sił powierzchniowych i objętościowych różnego pochodzenia a także modelowania procesu krystalizacji SP i morfologii przemian strukturalnych w SWC.

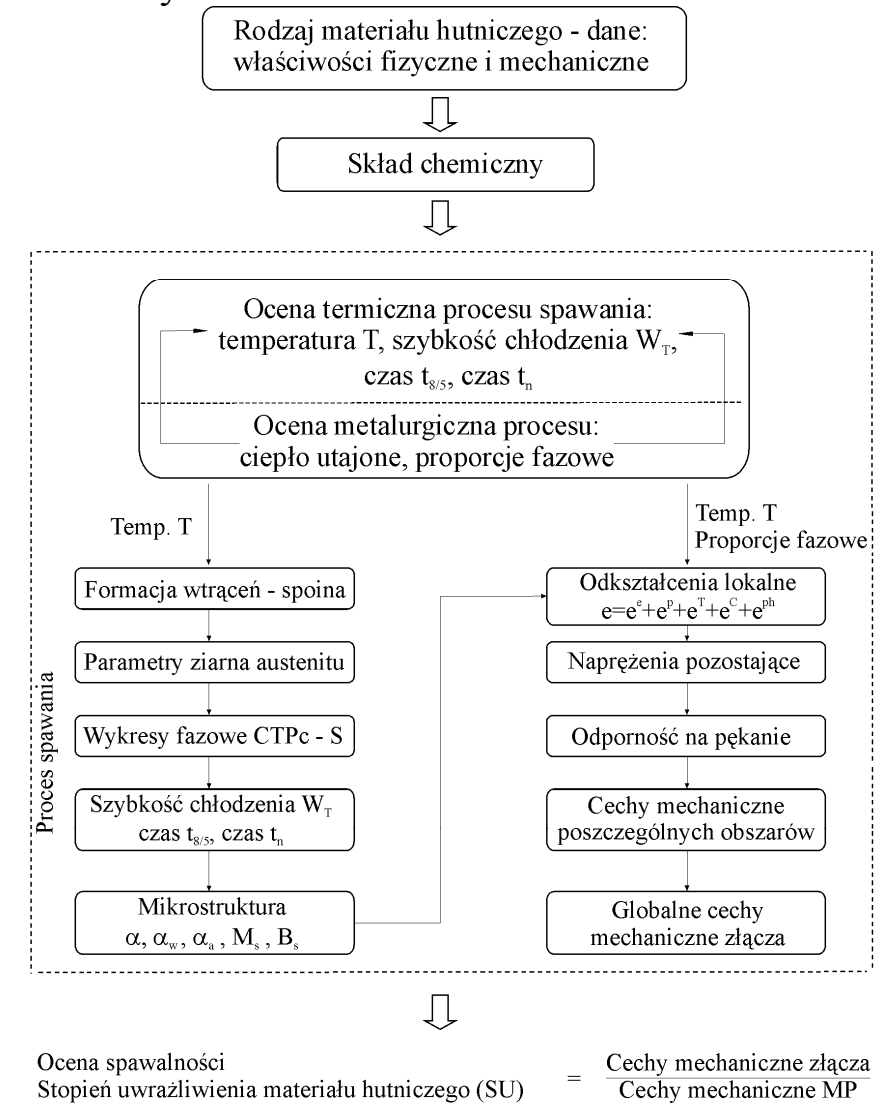

Rys. 1. Schemat obliczeń mikrostruktury oraz właściwości SP i SWC, gdzie:

$\varepsilon, \varepsilon^{e}, \varepsilon^{p}$, są odpowiednio odkształceniem całkowitym,

- sprężystym, plastycznym, termicznym, pełzaniem

$\varepsilon^{T}, \varepsilon^{c}, \varepsilon^{p h} \quad$ oraz przemianami fazowymi. 
Do oceny SU materiału praktycznie usiłuje się stosować normalizowane parametry mechaniki pękania np. $\mathrm{K}_{\mathrm{Ith}} / \mathrm{K}_{\mathrm{IC}} \mathrm{W}$ warunkach pękania zimnego lub w warunkach eksploatacyjnych $\delta / \delta_{\mathrm{c}}$ lub $\mathrm{J} / \mathrm{J}_{\mathrm{c}}[6]$. Wobec tego:

$$
\begin{aligned}
& S U_{1}=K_{I t h} / K_{I C} \\
& S U_{2}=\delta / \delta_{c} \neq J / J_{c} \\
& S U_{1} \neq S U_{2}
\end{aligned}
$$

$\mathrm{Z}$ powyższego wynika więc, iż nie istnieje jeden parametr $\mathrm{w}$ sposób globalny określający stopień uwrażliwienia na proces spawania, co niewątpliwie komplikuje ocenę spawalności materiałów hutniczych na etapie ich wytwarzania oraz w procesie spawania. Należy stwierdzić, iż cechy mechaniczne kształtują się już na etapie początkowym krystalizacji spoiny

W czasie chłodzenia jeziorka spawalniczego, w zakresie temperatur $2300 \div 800^{0} \mathrm{~K}$, rozpuszczony tlen oraz odtleniacze reagują w cieczy jeziorka, tworząc złożone wtrącenia tlenkowe o wymiarach od 0,1 do $1 \mu \mathrm{m}$. W zakresie temperatur $1800 \div 1600^{\circ} \mathrm{K}$ krystalizacja cieczy w ferryt $\delta$ rozpoczyna się i rozwija się od wtrąceń tlenkowych. Po całkowitej transformacji ferrytu $\delta \mathrm{w}$ austenit $\gamma \mathrm{w}$ zakresie temperatur $1100 \div 500^{\circ} \mathrm{K}$ następuje transformacja austenitu $\gamma \mathrm{w}$ różne postaci ferrytu: początkowego, Widmanstättena i iglastego [4]. Zasadniczo, do tej pory, nie ma kompleksowego modelu, który pozwalałby ująć wszystkie procesy $\mathrm{w}$ jednolitą teorię. Proces modelowania struktury spoiny wymaga więc przyjęcia makroskopowej skali opisu fizycznego transportu ciepła i przepływu płynu oraz mikroskopowej skali zarodkowania ziaren i ich rozrostu. Reasumując, aktualnie stosowane metody są używane do teoretycznej i numerycznej symulacji oraz modelowania mikrostruktury, bazują głównie na:

- termodynamicznej metodzie opisu przemian fazowych,

- termomechanicznej symulacji mechanizmu transformacji fazowych,

- kinetycznej metodzie oceny przemian fazowych - analitycznej i numerycznej,

- transporcie ciepła i masy.

\section{Jakość spoiny jako składowa w metodzie oceny dzialania obiektów technicznych}

Niniejsza metoda dotyczy oceny jakości działania złożonych systemów socjotechnicznych i eksploatowanych $\mathrm{w}$ nich obiektów technicznych. System to zbiór elementów, relacji między nimi i funkcji celów. 
Elementami systemów są obiekty - urządzenia techniczne, ich elementy składowe a wśród nich również takie, których łączenia zostały wykonane metodą spajania. Jakość działania systemów (lub ich elementów) opisuje zbiór istotnych cech, wyrażonych za pomocą wartości liczbowych, w danej chwili t, wyznaczających stopień spełnienia stawianych wymagań [7]. Tak zdefiniowane pojęcie jakości było podstawą do zbudowania jakościowego modelu ocenowego.

W celu zbudowania takiego modelu, należy wyznaczyć zbiór istotnych cech jakości $\mathrm{Z}=\mathrm{X}_{\mathrm{i}}, \mathrm{i}=1,2, \ldots, \mathrm{p}$, który dzieli się na $\mathrm{n}$ - rozłącznych podzbiorów $\mathrm{Z}_{1}, \mathrm{Z}_{2}, \ldots, \mathrm{Z}_{\mathrm{n}}$ spełniających zależność:

$Z_{i} \cap Z_{j}=\varnothing$ dla $i \neq j$;

$Z(t)=Z_{1}(t) \cup Z_{2}(t) \cup \ldots \cup Z_{n}(t)$

Każdy z n-tych podzbiorów $\mathrm{Z}_{\mathrm{i}}$, gdzie: $\mathrm{i}=1,2, \ldots, \mathrm{n}$, jest składową zbióru cech opisującego jakość działania całego systemu [7]. Zatem ogólną postać modelu można wyrazić następującą zależnością:

$$
\begin{aligned}
& Z_{1}(t)=\left\{X_{1}(t), \ldots, X_{k_{1}}(t)\right\} \\
& Z_{2}(t)=\left\{X_{k_{1}+1}(t), \ldots, X_{k_{2}}(t)\right\} \\
& Z_{3}(t)=\left\{X_{k_{2}+1}(t), \ldots, X_{k_{3}}(t)\right\} \\
& \ldots \\
& Z_{n}(t)=\left\{X_{k_{n}-r}(t), \ldots, X_{k_{n}-1}(t), X_{k_{n}}(t)\right\}
\end{aligned}
$$

gdzie:

$\mathrm{k}_{\mathrm{n}}=\mathrm{p} ; \mathrm{n} \leq \mathrm{p} ; \mathrm{k}, \mathrm{n}, \mathrm{r}, \mathrm{p} \in \mathrm{N}$;

$\mathrm{Z}_{\mathrm{i}}$ - podzbiory cech opisujące jakość poszczególnych podzbiorów elementów systemu $\mathrm{E}_{\mathrm{i}}$,

$\mathrm{E}_{\mathrm{i}}$ - podzbiory elementów systemu,

$\mathrm{X}_{\mathrm{i}}$ - zbiór cech opisujących całościowo jakość systemu, $\mathrm{i}=1,2, \ldots, \mathrm{p}$,

$\mathrm{i}=\left\{1<\ldots<\mathrm{k}_{1}<\mathrm{k}_{1}+1<\ldots<\mathrm{k}_{2}<\mathrm{k}_{2}+1<\ldots<\mathrm{k}_{\mathrm{n}} \mathrm{r}<\ldots<\mathrm{k}_{\mathrm{n}}-1<\mathrm{k}_{\mathrm{n}}=\mathrm{p}\right\}$.

$\mathrm{W}$ przypadku, gdy jednym $\mathrm{z}$ kryteriów będzie ocena spawalności elementów konstrukcyjnych danego obiektu technicznego $\left(Z_{\mathrm{k}}\right)$, to zgodnie ze schematem przedstawionym na rys. 1, kryterium takie opisane zostanie dwoma zbiorami cech dotyczącymi: właściwości fizycznych i mechanicznych oraz składu chemicznego materiałów, z których wykonane są elementy obiektów technicznych. W pierwszym $\mathrm{z}$ wymienionych zbiorów można wyróżnić dwa podzbiory zawierające cechy dotyczące metalurgii i struktury materiału $Z_{\mathrm{ms}}(\mathrm{t})$ [formacja wtrąceń, parametry ziarna austenitu, wykresy fazowe - CTPc-S, szybkość chłodzenia i mikrostruktura 
- $Z_{m s 1}(t)-Z_{m s 5}(t)$ ] oraz cechy mechaniczne $Z_{m}(t)$ [odkształcenia lokalne, naprężenia pozostające, odporność na pękanie, cechy mechaniczne poszczególnych obszarów, globalne cechy mechaniczne złącza $-\mathrm{Z}_{\mathrm{m} 1}(\mathrm{t})+$ $\left.\mathrm{Z}_{\mathrm{m} 5}(\mathrm{t})\right]$.

W związku z powyższym część modelu ocenowego, dotyczącą jakości spoiny $\left(Z_{\mathrm{k}}\right)$ można opisać zależnością:

$Z_{k}(t)=Z_{m s}(t)+Z_{m}(t)$

gdzie:

$Z_{m s}(t)=Z_{m s 1}(t)+Z_{m s}(t)+Z_{m s 3}(t)+Z_{m s}(t)+Z_{m s}(t) ;$

$\mathrm{Z}_{\mathrm{m}}(\mathrm{t})=\mathrm{Z}_{\mathrm{m} 1}(\mathrm{t})+\mathrm{Z}_{\mathrm{m} 2}(\mathrm{t})+\mathrm{Z}_{\mathrm{m} 3}(\mathrm{t})+\mathrm{Z}_{\mathrm{m} 4}(\mathrm{t})+\mathrm{Z}_{\mathrm{m} 5}(\mathrm{t})$.

czyli:

$Z_{k}(t)=\left[Z_{m s 1}(t)+Z_{m s 2}(t)+Z_{m s 3}(t)+Z_{m s 4}(t)+Z_{m s}(t)\right]+$

$+\left[Z_{m 1}(t)+Z_{m 2}(t)+Z_{m 3}(t)+Z_{m 4}(t)+Z_{m 5}(t)\right]$

Opisana zależnością (5) jakość połączenia spawalniczego stanowi składową oceny jakości wykonania danego elementu a w następstwie obiektu technicznego - maszyny, urządzenia, co z kolei bezpośrednio ma wpływ na jakość działania systemu, w którym jest on eksploatowany.

\section{Ocena jakości wykonania spoiny $P M$ jako rezultat PT i EM na przykładzie wzrostu pęknięcia}

$\mathrm{Z}$ zestawienia przedstawionego na Rys.1 wynika, że ocena termiczna procesu spawania sprzężona jest $\mathrm{z}$ metalurgiczną transformacją - od formacji wtrąceń do kształtowania mikrostruktury, ale o charakterze heterogenicznym. W zależności od natury procesu spawania trudno jest zapewnić jakość indywidualnych połączeń spawanych. Zasadniczo połączenia spawane zawierają więcej wad, aniżeli otaczający materiał rodzimy. Jest to jeden z ważniejszych problemów technologicznych w celu uzyskania optymalizacji: kosztu, wytrzymałości i odporności na pękanie złączy spawanych oraz poprawnej oceny spawalności a w ich następstwie bezpieczeństwa i niezawodności eksploatowanych obiektów technicznych lub ich elementów. Aktualnie uznaje się, iż w stadium początkowym mikroskopowy mechanizm pękania $\mathrm{w}$ złączu spawanym jest powiązany $\mathrm{z}$ formacją nieciagłości w postaci jam (dziur), ich wzrostem i wzajemnym łączeniu. Zakłada się również, iż jamy powstają przy wtrąceniach i są cylindryczne. W połączeniach spawanych rolę tę pełnią głównie tlenki, 
siarczki oraz węgliki. Naprężenia w sąsiedztwie nieciagłości możemy określić ze związku [2]:

$$
\sigma=\frac{K}{\sqrt{\pi(r+\delta)+\sqrt{\pi r}}} \sqrt{\frac{\sqrt{1-\left(v^{2} / c_{d}^{2}\right) \sin ^{2} \Theta}+\cos \Theta}{1-\left(v^{2} / c_{d}^{2}\right) \sin ^{2} \Theta}}
$$

gdzie: K- współczynnik intensywności naprężenia, v - prędkość wierzchołka pęknięcia, $c_{d}$ - prędkość propagacji bezwirowych fal, r, $\Theta$ współrzędne biegunowe z początkiem usytuowanym w wierzchołku pęknięcia,

oraz:

$\delta=\frac{\kappa K^{2}}{\sigma_{o}^{2}}$

jest wprowadzone do (6) w celu usunięcia osobliwości. Na przykład, jeżeli $\kappa=0,025$, to $[2]$ :

$$
\sigma_{\max }=\frac{\sigma_{o}}{\sqrt{0,025 \pi}}=3,6 \sigma_{o}
$$

Wzrost promienia cylindrycznego otworu „a" następuje zgodnie z zależnością:

$\frac{1}{a} \frac{d a}{d t}=\beta\left(\frac{\sigma}{\sigma_{o}}-1\right)^{n} ; \quad \sigma>\sigma_{\mathrm{o}}$

gdzie: a - promień cylindrycznego otworu, $\mathrm{t}$ - czas, $\beta$ - stała (parametr płynności), $\sigma_{o}$ - stałe naprężenie.

Otwory tworzą się przy cząsteczkach „i” gdy naprężenia wzrastają ponad pewną krytyczną wartość $\sigma_{\mathrm{el}}$, która zależy od wymiaru cząsteczki:

$\sigma_{e l}^{(i)}=\operatorname{sof} \sigma_{o}\left[1+\left(\frac{b_{o}}{a_{i}}\right)^{1 / 2}\right]$

gdzie: $a_{i}$ - promień cząsteczki, $b_{o}$ - standardowa wartość promienia cząsteczki, sof - współczynnik charakteryzujący kombinację osnowy cząsteczek.

Równania $(6 \div 10)$ stanowią matematyczną charakterystykę modelu, ilustrującego mikroskopowy proces wytężenia materiału $\mathrm{W}$ pobliżu wierzchołka pęknięcia [2] z uwzględnieniem cząsteczek - wtrąceń niemetalicznych. Problem ten nieco inaczej określono bazując na modelu makroskopowym, określonym w opracowaniach [6,1]. W obydwu 
przypadkach uwzględniono wpływ heterogeniczności biorąc pod uwagę parametry charakteryzujące wpływ więzów mechanicznych w procesie oceny odporności na pękanie, opartym o klasyczne rozwiązania mechaniki pękania.

Dla przykładu, dla płyt podczas jedno- lub dwuosiowego rozciagania, dokonano oceny parametrów charakteryzujących wpływ więzów mechanicznych jako [1]:

$Q=\left(\sigma_{\Theta \Theta}-\sigma_{\Theta \Theta}^{s s y}\right) / \sigma_{y}$

$Q_{m}=\left(\sigma_{h}-\sigma_{h}^{s s y}\right) / \sigma_{y}$

$H=\sigma_{h} / \sigma_{e}-\left(\sigma_{h} / \sigma_{e}\right)^{s s y}=h-h^{s s y}$

gdzie: $\mathrm{Q}, \mathrm{Q}_{\mathrm{m}}, \mathrm{H}-$ parametry definiujące więzy mechaniczne, $\sigma_{\Theta \Theta}$ naprężenie rozwarcia szczeliny, $\sigma_{\mathrm{h}}$ - naprężenie hydrostatyczne, $\sigma_{\mathrm{e}}-$ efektywne naprężenie Hubera-Misesa, $\sigma_{\mathrm{y}}$ - granica plastyczności.

Użyte oznaczenie ssy wskazuje sąsiedztwo wierzchołka pęknięcia z najwyższą wartością więzów mechanicznych. Wszystkie wielkości $\mathrm{w}$ równaniach (11-13) są określone $\mathrm{z}$ odległości $\mathrm{r} /\left(\mathrm{J} / \sigma_{\mathrm{y}}\right)=2$ od wierzchołka pęknięcia w cylindrycznym układzie współrzędnych $(r, \Theta)$. W oparciu o proces modelowania: analityczny i numeryczny, zgodnie z ustaleniami Burstow'a [3], na Rys.2 przedstawiono - dla 3-punktowego zginania - wpływ więzów mechanicznych jako rezultatu lokalnego zróżnicowania struktury w układzie normalizowanych parametrów.

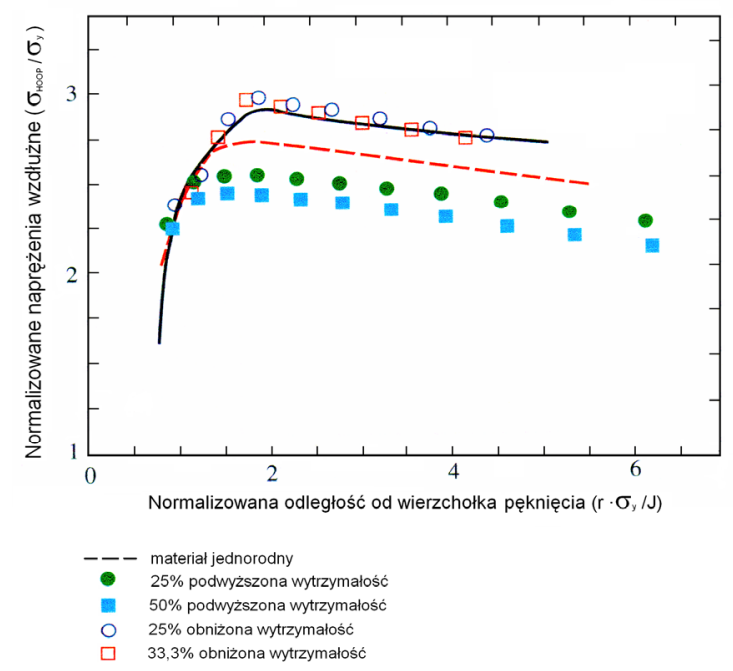

Rys.2. Naprężenia przed frontem pęknięcia. 
W praktyce oznacza to istotny wpływ na pękanie połączeń spawanych, co decyduje m.in. o spawalności materiałów i konstrukcji i ich wpływ na eksploatację urządzeń technicznych z punktu widzenia ich bezpieczeństwa i niezawodności.

\section{Podsumowanie}

Istotnym osiągnięciem współczesnej myśli technicznej w zakresie inżynierii spawania jest pogłębiona wiedza inżynierska, wyrażona m.in. przez „Obliczeniową Mechanikę Spawania” (OMS). W pierwszej kolejności, w ramach syntezy OMS, przedyskutowano schemat obliczeń mikrostruktury oraz właściwości SP i SWC oraz transformacji spoiny ze stali niskostopowej przy chłodzeniu ciagłym. Problem ten uwzględniono przy ocenie cech mechanicznych spoiny, na przykładzie wzrostu pęknięcia na poziomie mikroskopowym, $\mathrm{z}$ uwzględnieniem formacji nieciągłości w spoinie, charakteryzując również model makroskopowy. Powyższa analiza wskazuje na dużą użyteczność praktyczną OMS w procesie opracowania dokumentacji technicznej do realizacji zadań w budowie współczesnych konstrukcji obiektów technicznych oraz jej wpływu na jakość ich działania w procesach eksploatacji.

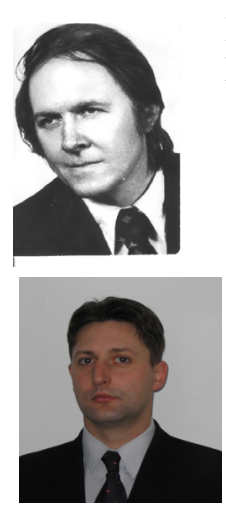

Prof. dr hab. inż. Eugeniusz Ranatowski, University of Technology and Life Science in Bydgoszcz, Mechanical Department, Chair of Material Science and Engineering, Poland

Dr inż. Lukasz Muślewski, University of Technology and Life Science in Bydgoszcz, Mechanical Department, Material Science and Engineering, Poland 